\title{
Evaluation of Corrosion Behaviour of Grey Cast Iron and Low Alloy Steel in Cocoa Liquor and Well Water
}

\author{
John Oluyemi Olawale ${ }^{1}$, Jamiu Kolawole Odusote ${ }^{2}$, Abuldkarim Baba Rabiu², \\ Emmanuel Onazi Ochapa ${ }^{2}$ \\ ${ }^{1}$ Department of Materials Science and Engineering Obafemi Awolowo University, Ile-Ife, Nigeria \\ ${ }^{2}$ Department of Mechanical Engineering University of Ilorin, Ilorin, Nigeria \\ Email: oolawale@oauife.edu.ng
}

Received October 21, 2012; revised January 5, 2013; accepted January 31, 2013

\begin{abstract}
Corrosion behaviour of cast iron and low alloy steel in cocoa liquor and well water was investigated. The average weight losses of the specimens were measured using digital weighing balance. The results showed that the weight losses of both cast iron and low alloy steel in both media increases with time. Corrosion rate of cast iron in cocoa liquor increases rapidly with time for up to 336 hours $(1000 \mu \mathrm{m} / \mathrm{yr})$, but in well water the rapid rate of corrosion only lasted up to 187 hours $(1160 \mu \mathrm{m} / \mathrm{yr})$ thereafter it continuously dropping until 264 hours $(667 \mu \mathrm{m} / \mathrm{yr})$ after which it remains constant. Low alloy steel corroded faster in cocoa liquor up to 264 hours $(200 \mu \mathrm{m} / \mathrm{yr})$, whereas the initial rapid corrosion rate only lasted up to 168 hours $(180 \mu \mathrm{m} / \mathrm{yr})$ in well water environment. The results revealed that low alloy steel exhibited better corrosion resistance in both media, with cocoa liquor been more aggressive. Thus, low alloy steel will be a better material for piping and pumping system in cocoa processing industries.
\end{abstract}

Keywords: Corrosion; Grey Cast Iron; Low Alloy Steel; Cocoa Liquor; Well Water

\section{Introduction}

Grey cast iron is a high carbon ferrous material that was previously been used for water and wastewater services pipes in several parts of the globe [1,2]. Most of the carbon in this material is in the form of continuous network of flake graphite platelets, which are dispersed throughout the metal matrix. This matrix is the major factor controlling its mechanical properties and is responsible for its relative weakness and lack of ductility [3]. Grey cast iron pipes have tendency to corrode in aggressive environment and subsequently fail due to their brittle nature $[4,5]$. A combination of factors which may include corrosion damage, external loading, internal pressure and manufacturing flaws also contribute significantly to the failure of these pipes [4,5]. This failure becomes accelerated as the pipes age resulting into leakages [6]. This will eventually resulted in increased expenditure on pipe rehabilitation, repair or replacement. In order to prevent this type of failure, efforts were geared towards finding alternative high corrosion resistance alloys in both water and other similar environments [7].

Low-alloy steels are low carbon ferrous material that contain additional alloying elements such as chromium, nickel, and molybdenum, and thus exhibit mechanical properties superior to those of cast iron and ordinary carbon steels [8]. The primary function of the alloying elements in most of the low-alloy steels is either to reduce environmental degradation under certain specified service conditions and/or increase hardenability in order to optimize mechanical properties and toughness after heat treatment. Although, low alloy steels may be relatively expensive and more complex to fabricate compared with grey cast iron, but are more likely to possess higher corrosion resistance in water and water-based liquid. Thus, they are used in a broad spectrum of applications based on their potential high corrosion resistance, especially in moderately corrosive environments, where small additions of some alloying elements will enhance corrosion resistance [8].

Many authors have performed failure analysis of grey cast iron pipes in water and wastewater environments [9-19], and corrosion behavior of low alloy steel in similar environments [20-24]. However, nothing was found in the literature on the investigation of these materials in cocoa liquor. Thus, the objective of the present study is to examine the corrosion rate of grey cast iron and low alloy steel pipes used in cocoa liquor processing plants. The results were also compared with their corrosion rates in well water.

\section{Materials}

The materials used for this study are cocoa liquor, well 
water, cast iron and low alloyed steel. The chemical composition of cocoa liquor was evaluated by chemical analysis and the result is as presented in Table 1, while the chemical compositions of cast iron and low alloyed steel were evaluated by spectrometer and the results were presented in Tables 2 and 3, respectively.

Table 1. Composition of cocoa liquor.

\begin{tabular}{cccc}
\hline Constituent & $\begin{array}{c}\text { Average Content } \\
(\mathrm{wt} \%)\end{array}$ & Constituent & $\begin{array}{c}\text { Average Content } \\
(\mathrm{wt} \%)\end{array}$ \\
\hline Crude Protein & 10.24 & Hydrogen & 5.74 \\
Fat & 21.60 & Phosphorus & 4.70 \\
Crude Fiber & 0.14 & Potassium & 75.60 \\
Ash & 1.07 & Calcium & 1.86 \\
Moisture Content & 1.50 & Magnesium & 1.18 \\
Dry Matter & 75.40 & Iron & 3.48 \\
Nitrogen & 3.94 & Zinc & 2.90 \\
Carbon & 24.64 & Copper & 1.40 \\
Sulphur & 12.60 & Manganese & 2.67 \\
\hline
\end{tabular}

Table 2. Chemical composition of cast iron.

\begin{tabular}{cccc}
\hline Element & Composition (\%) & Element & Composition (\%) \\
\hline $\mathrm{C}$ & 3.310 & $\mathrm{~V}$ & 0.0088 \\
$\mathrm{Si}$ & 2.190 & $\mathrm{Ti}$ & 0.0120 \\
$\mathrm{Mn}$ & 0.520 & $\mathrm{~Pb}$ & 0.0160 \\
$\mathrm{P}$ & 0.086 & $\mathrm{Mg}$ & 0.0028 \\
$\mathrm{~S}$ & 0.099 & $\mathrm{Sn}$ & 0.0340 \\
$\mathrm{Cr}$ & 0.296 & $\mathrm{As}$ & 0.0130 \\
$\mathrm{Mo}$ & 0.021 & $\mathrm{Co}$ & 0.0084 \\
$\mathrm{Ni}$ & 0.065 & $\mathrm{Bi}$ & 0.0053 \\
$\mathrm{Cu}$ & 0.208 & $\mathrm{Fe}$ & 93.100 \\
$\mathrm{Al}$ & 0.010 & & \\
\hline
\end{tabular}

Table 3. Chemical composition of low alloy steel.

\begin{tabular}{cccc}
\hline Element & Composition (\%) & Element & Composition (\%) \\
\hline $\mathrm{C}$ & 0.273 & $\mathrm{~V}$ & 0.0180 \\
$\mathrm{Si}$ & 0.203 & $\mathrm{Al}$ & 0.0006 \\
$\mathrm{Mn}$ & 0.650 & $\mathrm{Zn}$ & 0.0034 \\
$\mathrm{P}$ & 0.035 & $\mathrm{Sn}$ & 0.0204 \\
$\mathrm{~S}$ & 0.054 & $\mathrm{As}$ & 0.0009 \\
$\mathrm{Cr}$ & 0.169 & $\mathrm{Co}$ & 0.0124 \\
$\mathrm{Mo}$ & 0.011 & $\mathrm{~W}$ & 0.0878 \\
$\mathrm{Ni}$ & 0.119 & $\mathrm{Fe}$ & 98.0413 \\
$\mathrm{Cu}$ & 0.349 & & \\
\hline
\end{tabular}

\section{Method}

Test pieces were selected from cast iron and low alloyed steel, and machined to 6 inches square. Fourteen samples each were produced from cast iron and low alloyed steel. Each of the samples was degreased, cleaned, weighed, and tightened to the end of strings attached to retort stands. The specimens were then fully immersed in cocoa liquor and well water inside the beakers without touching its bottom. The beakers with the specimens were then covered with filter papers to prevent contamination of the media. The first sample was withdrawn from both the cocoa liquor and well water after 72 hours (3 days), washed with ethanol, scrubbed with brush, dried, and weighed again using digital weighing balance. The process continued for a total period of 40 days at 3 days interval. From the measured weight loss data, the weight loss, $W$ was calculated using Equation (1).

$$
W=W_{o}+W_{f}
$$

where $W_{o}$ and $W_{f}$ are the initial weight before immersion and final weight of the specimens after immersion, respectively.

At the end of 960 hours of exposure, the data collected was used to calculate the corrosion rates of both the cast iron and low alloyed steel in cocoa liquor and well water. The corrosion rates were evaluated using Equation (2)

$$
\text { Corrosion Rate }(\mu \mathrm{m} / \mathrm{yr})=534 w / \text { oat }
$$

where $w$ is the weight loss in $g, \rho$ is the densities of the specimens, $a$ is the area of exposure in $\left(\mathrm{cm}^{2}\right)$, and $t$ is the time in hours [21].

\section{Results and Discussions}

Cocoa liquor contains crude protein and fat (Table 1). Crude protein is responsible for gradual degradation of both grey cast irons and low alloy steel while fat inhibits their degradation when exposed to cocoa liquor. However, degradation of grey cast irons and low alloy steel when exposed to well water was possibly due to oxidation as a result of the presence of oxygen in well water. The relationship between weight loss/area $\left(\mathrm{g} / \mathrm{cm}^{2}\right)$ and exposure time of both the cast iron and low alloy steel samples in cocoa liquor and well water are shown in Figures 1 and 2. The relationship between corrosion rate and exposure time of both cast iron and low alloy steel in cocoa liquor and well water are presented in Figures 3 and 4.

From Figures 1 and 2, it was observed that weight loss of the samples increased with exposure time. However, the rate of weight loss of cast iron was rapid in both cocoa liquor and well water while that of low alloy steel is gradual. The rate of weight loss of low alloyed steel is gradual because of presence of nickel, chromium and 


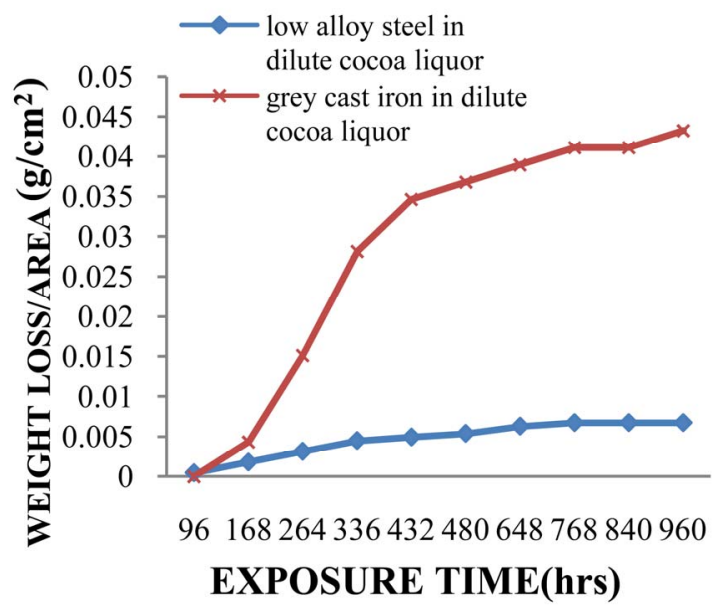

Figure 1. The curve showing the graph of weight loss/area $\left(\mathrm{g} / \mathrm{cm}^{2}\right)$ to the exposure time (hrs) of low alloy steel and grey cast iron in cocoa liquor.

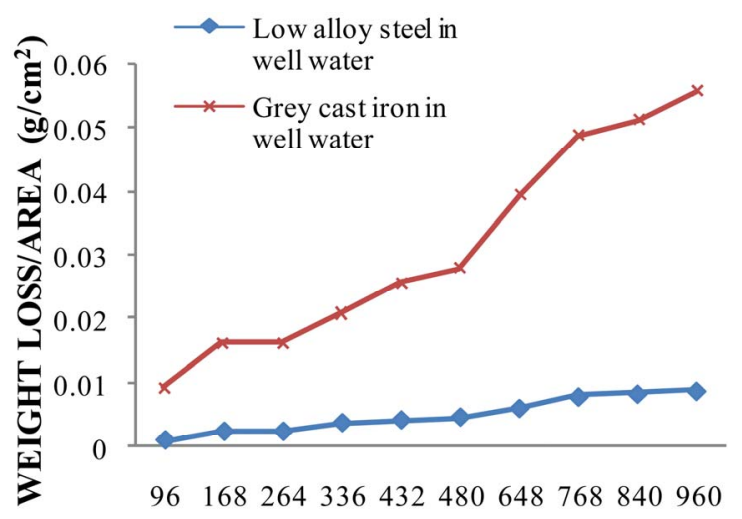

EXPOSURE TIME (hrs)

Figure 2. Curve showing the graph of weight loss/area $\left(\mathrm{g} / \mathrm{cm}^{2}\right)$ to exposure time (hrs) of low alloy steel and grey cast iron in well water.

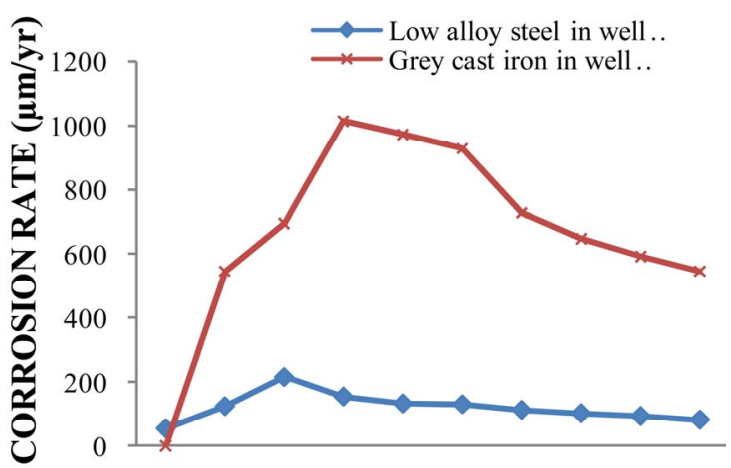

$\begin{array}{llllllllll}96 & 168 & 264 & 336 & 432 & 480 & 648 & 768 & 840 & 960\end{array}$

EXPOSURE TIME (hrs)

Figure 3. Curve showing the relationship between corrosion rate $(\mu \mathrm{m} / \mathrm{yr})$ and exposure time (hrs) of low alloy steel in well water and grey cast iron in well water. copper which inhibit corrosion. Nickel increases corrosion resistance by the formation of protective oxide films on the surfaces of the steel. Chromium added to steel alone and in combination with nickel increase the corrosion resistance of steel. As with nickel, small additions of chromium are used to refine the grain and matrix microstructures [25]. These refinements enhance the corrosion resistance of steel both in well water and cocoa liquor. Chromium also, increases the corrosion resistance of steel by the formation of protective oxides on its surfaces. The oxides formed will resist oxidation and hence the rate of weight loss. Copper additions of 0.25 to $1 \%$ increase the resistance of steel to corrosion in aqueous environment [25]. Small additions of copper have been found to enhance atmospheric corrosion resistance of steel and its additions to nickel- chromium alloy steel have been found to increase corrosion resistance [25].

It was also observed that the weight loss of both metals in well water is more than in cocoa liquor. This can be attributed to the high concentration of oxygen in well water as against the concentration of oxygen of crude protein in cocoa liquor. Dissolved oxygen is an important electron acceptor in the corrosion of metallic iron: $\mathrm{Fe}($ metal $)+0.5 \mathrm{O}_{2}+\mathrm{H}_{2} \mathrm{O} \leftrightarrow \mathrm{Fe}^{2+}+2 \mathrm{OH}^{-}$. It can also play a role in the oxidation of ferrous iron $\left(\mathrm{Fe}^{2+}\right)$ or iron scales, for example:

$\mathrm{Fe}^{2+}+0.25 \mathrm{O}_{2}+0.5 \mathrm{H}_{2} \mathrm{O}+2 \mathrm{OH}^{-} \leftrightarrow \mathrm{Fe}(\mathrm{OH})_{3}(\mathrm{~s})$. Thus, oxygen concentration can have varying effects on iron corrosion. As expected, the corrosion rate increases with increasing in dissolved oxygen [26]. Hence, the weight loss of iron in well water is more than in cocoa liquor.

The corrosion rate of cast iron in cocoa liquor increases with exposure time up to 336 hours

$(1000 \mu \mathrm{m} / \mathrm{yr})$ after which it continues to reduce but low alloy steel increases with exposure time up to 264 hours $(200 \mu \mathrm{m} / \mathrm{yr})$ after which it remains almost constant (Figure 3). The corrosion rate of cast iron in cocoa liquor increases in the first 336 hours of exposure time due to the effect of crude protein in cocoa liquor but the rate is subsequently reducing due to the presence of fat which inhibits further corrosion. Also, the corrosion rate of low alloy steel in cocoa liquor increases in the first 264 hours because of effect of crude protein but remain constant as a results of combined effects of inhibition due to the presence of fat in cocoa liquor and corrosion products which adhered to surface of steel and makes its surface chemically inactive when exposed to air or other oxygen-containing environments. Chromium that is present in low alloy steel is capable of forming an invisible, inert or passive, self-repairing oxide film on its surface. Chromium readily forms an oxide that is transparent and happens to be extremely resistant to further degradation. It is less noble than iron and, when alloyed with steel, tends to form its oxide first. It is this passive layer that gives low alloy steel its corrosion resistance after 264 
hours exposure time. This is phenomenon of passivation which caused the formation of a film on the surface of the sample and prevents further corrosion.

In the well water, the corrosion rate of cast iron is high in the first 187 hours $(1160 \mu \mathrm{m} / \mathrm{yr})$ thereafter it continuously dropping until 264 hours $(667 \mu \mathrm{m} / \mathrm{yr})$ after which it remains constant (Figure 4). Also, the rate of corrosion of low alloy steel is high in the first 168 hours $(180 \mu \mathrm{m} / \mathrm{yr})$ and thereafter it remains constant. The corrosion rate is very high in the first instance because of oxidation of iron in both metal but thereafter remains constant as a result of formation of oxides layer which prevents further corrosion. Since steels and cast iron are iron-based alloys, whenever they are exposed to water, aqueous corrosion will occur between irons $(\mathrm{Fe})$ and water $\left(\mathrm{H}_{2} \mathrm{O}\right)$ leading to the $\mathrm{Fe} \rightarrow \mathrm{Fe}^{2+}+2 \mathrm{e}^{-}$and $4 \mathrm{H}^{-}+\mathrm{O}_{2}+4 \mathrm{e}^{-} \rightarrow 2 \mathrm{H}_{2} \mathrm{O}$ reactions. Metal loss occurs on the surface of steel or cast-iron at the anode due to an oxidation reaction. Iron atoms enter into solution generating electrons: $\mathrm{Fe} \rightarrow \mathrm{Fe}^{2+}+2 \mathrm{e}^{-}$. Simultaneously, a spontaneous reduction reaction is occurring at the cathode. The reaction uses electrons generated at the anode in the reduction of oxygen or the reduction of hydrogen ions: $4 \mathrm{H}^{-}+\mathrm{O}_{2}+4 \mathrm{e}^{-} \rightarrow 2 \mathrm{H}_{2} \mathrm{O}$. Therefore, the overall reaction is: $2 \mathrm{Fe}+2 \mathrm{H}_{2} \mathrm{O}+\mathrm{O}_{2} \rightarrow 2 \mathrm{Fe}(\mathrm{OH})_{2}$. This an hydrous ferrous oxide $\left(\mathrm{FeO}+n \mathrm{H}_{2} \mathrm{O}\right)$ or ferrous hydroxide $\left[\mathrm{Fe}(\mathrm{OH})_{2}\right]$ composes the diffusion-barrier layer next to the iron surface through which $\mathrm{O}_{2}$ must diffuse to cause further corrosion. This oxide layer "passivates" the underlying metal in the sense that it forms a protective layer that causes the surface to lose its chemical reactivity and prevents further oxidation. Furthermore, the high corrosion resistance of low alloy steel in well water as compared with cast iron can be attributed to the presence of nickel, chromium and copper that inhibits corrosion.

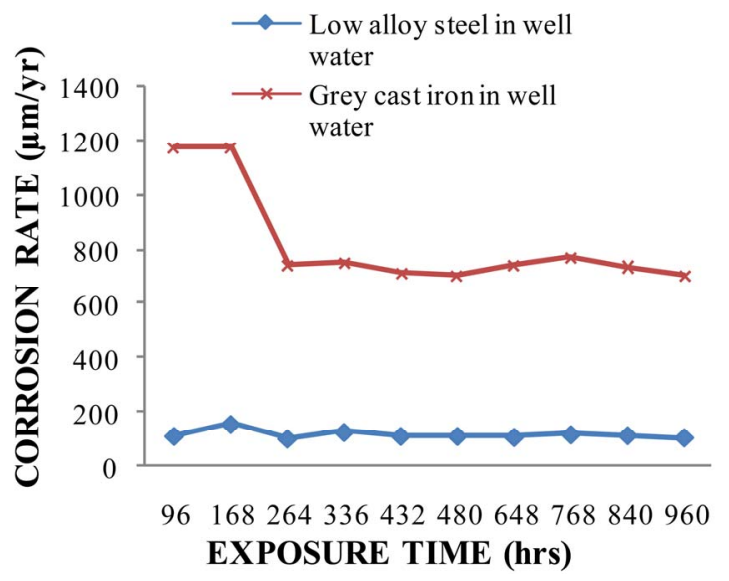

Figure 4. Curve showing the relationship between corrosion rate $(\mu \mathrm{m} / \mathrm{yr})$ and exposure time (hrs) of low alloy steel and grey cast iron in well water.
Comparing the results presented in Figures 3 and 4, grey cast iron is more corrosive in well water $(1600 \mu \mathrm{m} / \mathrm{yr})$ than cocoa liquor $(1000 \mu \mathrm{m} / \mathrm{yr})$ while low alloy steel in cocoa liquor $(200 \mu \mathrm{m} / \mathrm{yr})$ than well water $(180 \mu \mathrm{m} / \mathrm{yr})$. Grey cast iron is more corrosive in well water because of high concentration of dissolved oxygen in well water as compared with crude protein of cocoa liquor. The combined effects of oxide film layer formed by chromium and hydrous ferrous oxides in well water were responsible for lower rate of corrosion of low alloy steel in well water as compared with cocoa liquor.

\section{Conclusion}

From the above analysis and discussion, it can be concluded that the rate of corrosion of grey cast iron is higher in both media than low alloy steel meaning that low alloy steel has better corrosion resistance than grey cast iron probably as a result of their chemical composition. It was also established that grey cast iron is more corrosive in well water than in cocoa liquor while low alloy steel in cocoa liquor than in well water. It is concluded that low alloy steel is a better material for piping and pumping system in cocoa processing industries.

\section{REFERENCES}

[1] G. J. Kirmeyer, W. Richards and C. D. Smith, "An Assessment of Water Distribution Systems and Associated Research Needs," American Water Works Association Research Foundation (90658), Denver, 1994.

[2] B. Rajani and S. McDonald, "Water Mains Break Data on Different Pipe Materials for 1992 and 1993," Report No. A-7019.1, National Research Council of Canada, Ottawa, 1995.

[3] E. P. Degarmo, J. T. Black and R. A. Kohser, "Materials and Processes in Manufacturing," 9th Edition, Wiley, Hoboken, 2003.

[4] R. E. Morris Jr., "Principal Causes and Remedies of Water Main Breaks," Journal of the American Water Works Association, Vol. 59, No. 7, 1967, p. 782.

[5] B. Rajani, C. Zhan and S. Kuraoka, "Pipe-Soil Interaction Analysis of Jointed Water Mains," Canadian Geotechnical Journal, Vol. 33, No. 3. 1996, pp. 393-404. doi:10.1139/t96-061

[6] D. K. O'Day, R. Weiss, S. Chiavari and D. Blair, "Water Main Evaluation for Rehabilitation/Replacement," American Water Works Association Research Foundation (90509), Denver, 1986.

[7] T. G. Oakwood, "Corrosion of Wrought Low-Alloy Steels," Corrosion: Materials, ASM Metal Handbook, Volume 13B, ASM International, Metals Park, Ohio, 2005, pp. 11-27.

[8] U. R. Evans, "The Corrosion and Oxidation of Metals: Scientific Principles and Practical Applications," Edward Arnold, London, 1960, p. 272. 
[9] J. Makar and B. Rajani, "Gray Cast Iron Water Pipe Metallurgy," ASCE Journal of Construction Materials, Vol. 12, 2000, pp. 245-253.

[10] J. A. Jakobs, "Underground Corrosion of Water Pipes in Canadian Cities - Case: The City of Calgary, Final Report," Caproco Corrosion Prevention Ltd., (CANMET Contract Report No. 0SQ81-00096, Canadian Centre for Mineral and Energy Technology, Energy, Mines and Resources Canada. Canadian Government Publishing Centre), Ottawa, 1985,

[11] R. P. Lee, "Systemized Failure Analysis-Some Unusual Failure Modes," Chemical Engineering, Vol. 84, No. 1, 1977, pp. 107-108.

[12] G. E. Arnold, "Experience with Main Breaks in Four Large Cities-Philadelphia," Journal of the American Water Works Association, Vol. 52, No. 8, 1960, p. 1041.

[13] P. J. De Rose and R. W. Parkinson, "Corrosion of Ductile Iron Pipe," Report TR241, WRc Engineering, Water Research Centre, Swindon, 1985.

[14] J. H. Fitzgerald, "Corrosion as a Primary Cause of CastIron Main Breaks," Journal of the American Water Works Association, Vol. 60, No. 8, 1968, p. 882.

[15] M. Romanoff, "Exterior Corrosion of Cast-Iron Pipe," Journal of the American Water Works Association, Vol. 56, No. 9, 1964, p. 1129.

[16] M. Zamanzadeh, et al., "Analysis of Failures in Water Mains," Materials Protection, 1990, pp. 50-53.

[17] J. J. Synder, "Failures of Iron Castings," ASM (American Society for Metals) Metals Handbook, 9th Edition, Vol. 11, Failure Analysis, Metals Park, Ohio, 1986.

[18] J. Q. Zhao, "McMaster Avenue Watermain Failure Final Assessment Report," CH2M Gore and Storrie Limited, Consulting Engineers, Toronto, 1996.
[19] A. Kottmann, "Pipe Damage Due to Air Pockets in Low Pressure Piping," Proceedings of 2nd International Conference on Water Pipeline Systems, Edinburgh, 24-26 May 1994, pp. 11-16.

[20] B. Hou, Y. T. Li, Y. X. Li and J. Zhang, "Effect of Alloy Elements on the Anti-Corrosion Properties of Low Alloy Steel," Bulletin of Materials Science, Vol. 23, No. 3, 2000, pp. 189-192. doi:10.1007/BF02719908

[21] O. Ogundare, I. M. Momoh, O. J. Akinribide, A. R. Adetunji, J. O. Borode, S. O. O. Olusunle and O. O. Adewoye, "Comparative Study of Corrosion Sensitivity of Selected Ferrous Metals in Crude Oil," Journal of Minerals \& Materials Characterization \& Engineering, Vol. 11, No. 6, 2012, pp. 559-568.

[22] C. Vikas, G. G. Prema and G. R. Bhagure, "Corrosion of Water Pipes: A Comprehensive Study of Deposits," Journal of Minerals \& Materials Characterization \& Engineering, Vol. 11, No. 5, 2012, pp. 479-492.

[23] M. A. Bodude, W. A. Ayoola, D. E. Esezobor and A. A. Agbeleye, "Corrosion-Wear of ST60-Mn Steel in Cassava Juice," Journal of Minerals \& Materials Characterization \& Engineering, Vol. 11, No. 2, 2012, pp.153-158.

[24] O. O. Daramola, B. O. Adewuyi and I. O. Oladele, "Corrosion Behaviour of Heat Treated Rolled Medium Carbon Steel in Marine Environment," Journal of Minerals \& Materials Characterization \& Engineering, Vol. 10, No. 11, 2011, pp. 888-903.

[25] P. R. Roberge, "Handbook of Corrosion Engineering," McGraw-Hill, New York, 2000.

[26] G. Gedge, "Corrosion of Cast Iron in Potable Water Service. Process, Corrosion and Related Aspects of Materials for Potable Water Supplies," Proceedings of the Institute of Materials Conference, London, 8-9 December 1992. 